\title{
Microbial food webs and the export of biogenic carbon in oceans*
}

\author{
Louis Legendre ${ }^{1}$, Jacques Le Fèvre ${ }^{2}$ \\ 'GIROQ, Département de biologie, Université Laval, Québec, Québec, Canada G1K 7P4 \\ ${ }^{2}$ Unité de Recherche 'Flux de Matière et Réponses du Vivant', Institut Universitaire Européen de la Mer, \\ Université de Bretagne Occidentale, BP 809, F-29285 Brest Cedex, France
}

\begin{abstract}
Microbial food webs, which comprise phototrophic picoplankton (or ultraplankton), heterotrophic bacteria and protozoa, are ubiquitous in marine waters. Members of the microbial food web may play various roles in the export of biogenic carbon. For example, it has been postulated that high bacterial activity may sometimes prevent a significant fraction of the production by large phytoplankton from reaching metazoan consumers. Phototrophic or heterotrophic small plankton cells may be readily exported (i.e. biological $\mathrm{CO}_{2}$ pump) if incorporated into large particles, through either endosymbiosis with larger cells, or development on material accumulated in hydrodynamic traps, or inclusion into marine snow, or grazing by large planktonic microphages (e.g. salps) and incorporation in their sometimes fast-sinking faecal pellets. Another aspect is the export of carbonate by members of the microbial food web (e.g. coccolithophores, foraminifera), which influences the carbon dioxide balance of the ocean (i.e. carbonate pump). Finally, carbon bound into refractory dissolved organic matter is chemically sequestered in the upper ocean, before being exported to depth. The activity of microbial food webs may therefore influence in several ways the export (and sequestration) of biogenic carbon in oceans.
\end{abstract}

KEY WORDS: Microorganisms · Plankton - Bacteria $\cdot$ Food web - Carbon flux

\section{INTRODUCTION - THE MICROBIAL FOOD WEB IN MARINE WATERS}

Microorganisms are ubiquitous in the world ocean. Even in the extreme environment of the sea ice, heterotrophic bacteria are present together with such protists as ciliates and foraminifera (refs. in Legendre et al 1992). In addition, although this is not widely recognized, small photosynthetically active algae (as small as < $1 \mu \mathrm{m}$; Legendre et al. 1987) may be present in the sea ice, but their significance remains to be assessed.

It has indeed become increasingly clear over the past 2 decades that microorganisms play a much larger role in marine food webs than previously thought. In a landmark paper, Pomeroy (1974) pointed out that the

\footnotetext{
- Contribution to the programmes of GIROQ (Groupe interuniversitaire de recherches océanographiques du Québec) and of Unités de Recherche 1363 and 1513, Centre National de la Recherche Scientifique (France)
}

classical textbook description of a chain from diatoms through copepods and krill to fishes and whales may in fact be only a small part of the flow of energy'. For instance, it is now widely acknowledged that, in oligotrophic oceanic waters, phototrophic picoplankton (cells 0.2 to $2 \mu \mathrm{m}$; Sieburth et al. 1978) or ultraplankton

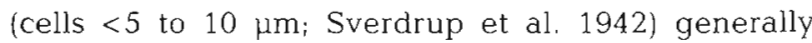
account for $>50 \%$ of the chlorophyll a biomass, with some published values $>90 \%$. Given their high proportions in the biomass, the small cells are responsible for a large proportion of the total primary production, typically ca 50 to $60 \%$. Pomeroy (1974) also hypothesized that microorganisms such as bacteria and protists could be major consumers in the sea, and account for a large fraction of global ocean respiration.

Azam et al. (1983) also stressed the importance of bacteria and protozoa in the ocean, and put forward the concept of a microbial food loop, in which bacteria are exploited, and controlled, by protozoa, including heterotrophic microflagellates which are in turn ex- 
ploited by ciliates. This grazing activity is accompanied by excretion of substances which are in turn used by the bacteria, so that the system more or less operates in a closed circuit. This leaves aside the role of picoplanktonic photoautotrophs, which are also part of the microbial food links. The 2 expressions microbial web and microbial loop are found in the literature. It has been proposed (e.g. Rassoulzadegan 1993) to use 'microbial loop' for designating the almost closed system of heterotrophic bacteria and zooflagellate grazers, in which the latter release dissolved organic matter used as substrate by the former, and 'microbial food web' for the more open system which also includes the autotrophic pico- and nanoplankton. According to Cushing (1989), the microbial food web predominates in stratified waters because the exudates from phototrophic picoplankton (small eukaryotic algae and cyanobacteria) are not dispersed and can therefore be used by heterotrophic bacteria.

Picophytoplankton could thus be viewed as competitors to large cells, such as diatoms, for nutrients, while the microheterotrophs can be viewed as competitors to metazoans, such as copepods and fish, in the utilization of primary production. According to a number of empirical data (e.g. Williams 1981, Ducklow et al. 1986, Pomeroy \& Deibel 1986, Smith et al. 1986) and modelling exercises (e.g. Taylor \& Joint 1990, Moloney et al. 1991), the microbial food web would thus constitute a $\sin k$ for biogenic carbon. In other words, most of the autotrophic production processed by microorganisms would be oxidized (respired) within the microbial loop in the euphotic layer (e.g. Michaels \& Silver 1988) rather than being exported in the form of metabolic energy to higher-order consumers, or in the form of particle fall-out to deep waters. For example, results of network analyses for 3 food webs (i.e. SE Atlantic oceanic waters, stratified water column of the Agulhas Bank, and Benguela coastal upwelling; Moloney et al. 1991 ) indicate that $<1 \%$ of the photosynthetically fixed carbon reaches heterotrophs $>25 \mu \mathrm{m}$ via heterotrophs $<25 \mu \mathrm{m}$.

However, even if the microbial web is inefficient as a carbon pathway to Iarge heterotrophs, it is the only available pathway when autotrophs are small. The above-cited study by Moloney et al. (1991) shows that the proportion of the carbon which reaches heterotrophs $>25 \mu \mathrm{m}$ directly from autotrophs may be as high as ca $90 \%$ on the Agulhas Bank and $>95 \%$ in the Benguela upwelling, while this proportion is almost nil in oceanic waters. This agrees with the results of Vézina \& Platt (1988) who found, using inverse methods to estimate fluxes in pelagic food webs, that microbial grazers (protozoans and microzooplankton) supplied ca $70 \%$ of the carbon demand of the mesozooplankton at a stratified station in the English Channel, and ca $40 \%$ at a station in the Celtic Sea. These examples, as well as other modelling exercises (e.g. Pace et al. 1984, Fasham 1985), suggest that the microbial food web can also function as a link towards metazoans. Furthermore, some large planktonic microphages appear rather efficient at both exploiting microbial resources and producing resistant, fast-sinking, particles (e.g. review of Fortier et al. 1994).

The sink versus link views of the role of microbial food webs in the ocean had to some extent developed into a controversy, whereas some authors (Sherr \& Sherr 1988) argued that the role of the microbial food web as a sink or a link for carbon is a non-issue, because all carbon for ingestion by metazoans must come from the microscopic part of the food web (all planktonic primary producers being microscopic). As pointed out by Ducklow (1991), however, the link-sink approach need not be considered an either-or issue. A number of microbial processes coexist in marine waters some of which (the link aspect) will favour the export of biogenic carbon, while others (the sink aspect) may delay or prevent it. This duality sets the general framework for the present paper, in which some of the microbial processes that influence the export of biogenic carbon in oceans are examined (Fig. 1). The following discussion will only cover a few of these processes, given our limited knowledge of microbial food webs in the marine environment. It is recognized that, by lack of sufficient information, some microbial processes that may eventually prove significant for the export of biogenic carbon have perhaps not been identified in the present paper.

\section{SOME MICROBIAL PROCESSES INFLUENCING THE EXPORT OF BIOGENIC CARBON}

\section{Export and sequestration of carbon in oceans: the biological $\mathrm{CO}_{2}$ pump}

Within the context of global climate change, 2 terms must be distinguished as to the flux of biogenic carbon in oceans, i.e. export and sequestration (see Legendre \& Le Fèvre 1991j. On the one hand, export refers to the flux of biogenic material from surface to depth, while on the other hand, sequestration concerns the removal of dissolved inorganic $\mathrm{CO}_{2}$ from the atmosphere and the surface waters for periods of interest to global warming (i.e. at least a few hundred years). Processes involved in carbon sequestration include: the sinking or downwards transport of biogenic dissolved and particulate carbon, followed by burial in sediments or dissolution in deep waters; the long-term fixation of carbon into calcareous material; and the binding of carbon into refractory dissolved organic matter. Export 


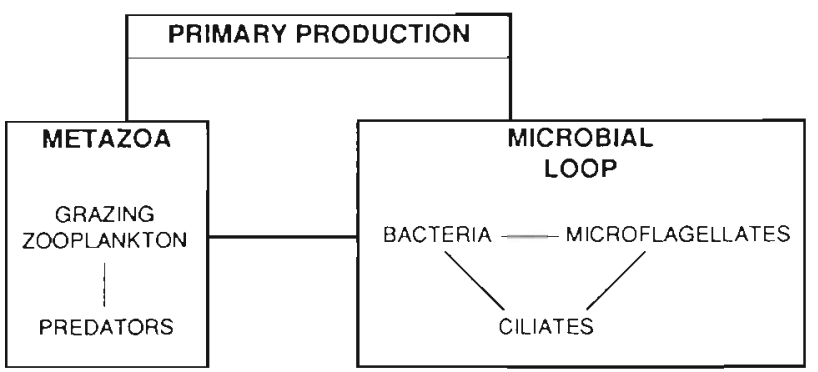

Fig. 1. Conceptual model of the flux of carbon between primary producers, metazoans and microorganisms (adapted from Pomeroy \& Wiebe 1988, Fig. 1). The number of transfers is variable and often unknown, for both the metazoans and the microbial food web

and sequestration are generally not equivalent, since a large fraction of the exported biogenic carbon is sometimes rapidly respired during its downwards transit and recycled back to the atmosphere. For global biogeochemical budgets, the really significant term is not the export, but the actual sequestration of carbon.

Close to the surface of the ocean (euphotic layer), solar light fuels the photosynthetic incorporation of inorganic carbon into organic molecules by phytoplankton, a fraction of which sinks to deep waters (as intact cells, faecal pellets, marine snow) or is actively transported by vertically migrating organisms. This export pathway is known as the biological $\mathrm{CO}_{2}$ pump, since the carbon supply used by the photosynthesis in the euphotic zone is replenished by diffusion of atmospheric $\mathrm{CO}_{2}$ into the oceans (and by $\mathrm{HCO}_{3}{ }^{-}$in river waters). This pump and other mechanisms operate in such a way that a gradient of increasing $\mathrm{CO}_{2}$ concentration towards deeper waters is maintained against the effects of turbulent mixing and diffusion (for more details, see for instance Volk \& Hoffert 1985).

As far as presently known, the biological $\mathrm{CO}_{2}$ pump is unlikely to directly increase carbon sequestration in a short-term response to the anthropogenic increase in atmospheric $\mathrm{CO}_{2}$ concentration. This is because marine photosynthesis is generally not carbon-limited. However, new findings (Riebesell et al. 1993) indicate that, under optimal light and nutrient conditions, the growth of diatoms might be limited by the supply of free $\mathrm{CO}_{2}$ in seawater, so that a response cannot be ruled out in some circumstances (see Raven 1993). The role of this pump in the global flux of carbon needs anyway to be quantified (see JGOFS 1990), because it does contribute to the overall balance in the exchanges between the various global carbon pools (see Sundquist 1985). In the long term, the biological $\mathrm{CO}_{2}$ pump and climate changes may interact. Biological activity in the oceans is likely to respond to climate changes, both directly (e.g. effects of temperature and cloud cover) and through climate-induced variations in the hydrodynamic forcing of biological production. If, through such effects, the net result of global warming were an enhancement of overall photosynthesis, this would result in a negative feedback, and climatic variations would be attenuated. The response of the biological $\mathrm{CO}_{2}$ pump to climate change may also, however, result in positive feedback effects such as those often put forward to account for glacial-interglacial oscillations. The latter are believed to be induced by a weak astronomical forcing whose effects are amplified by changes in $\mathrm{CO}_{2}$ concentration in the atmosphere. According to a modelling exercise by Lindstrom \& McAyeal (1989), a threshold of about 250 ppm (volume) in $\mathrm{CO}_{2}$ concentration would govern the evolution of climate towards either the glacial or the interglacial quasi-stable mode. Among other mechanisms put forward to account for the self-regulation of each mode, it has been hypothesized that the biological $\mathrm{CO}_{2}$ pump in the oceans is stronger in glacial conditions, and weaker in interglacial ones (e.g. because of latitudinal shifts in the location of the areas of maximal production such as major upwellings; Sarmiento \& Toggweiler 1984).

The present paper will examine the significance of microbial food webs for the biological $\mathrm{CO}_{2}$ pump. The discussion will deal with potential influence, on the export and sequestration of biogenic carbon, of 4 microbial processes, i.e. the possible competition between bacteria and metazoan consumers; the export pathways of small plankton cells, and their significance for the sequestration of carbon; the export of carbonate by some members of the microbial food web; and finally, the production of refractory dissoived organic matter.

\section{Bacteria versus metazoan consumers}

According to Pomeroy \& Deibel (1986), high secondary production in cold waters may be explained by low bacterial activity. At temperatures between -1 and $2^{\circ} \mathrm{C}$, as for example during the spring phytoplankton bloom in Newfoundland waters, photosynthetic production is substantial but rates of bacterial growth and metabolism are low (Fig. 2). Low rates of microbial utilization of phytoplankton material would allow a high proportion of the autotrophic production to find its way to metazoan consumers, i.e. benthic and planktonic invertebrates. According to Pomeroy \& Wiebe (1988), this would explain why regions in the northern hemisphere where the spring bloom occurs between -1.8 and $2^{\circ} \mathrm{C}$ are also regions of resilient fisheries of consistently high productivity. In warm tropical and subtropical waters, in contrast, bacterial metabolism and 


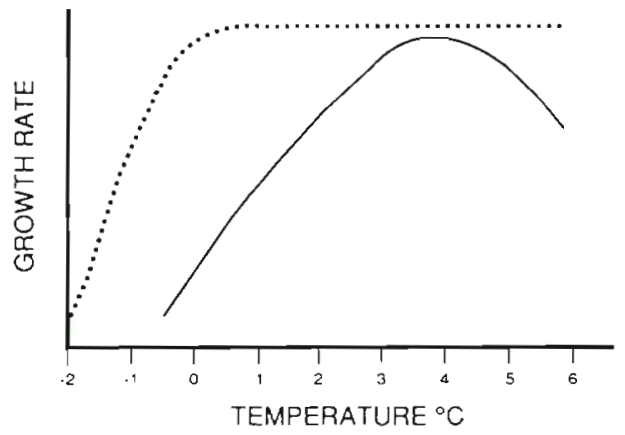

Fig. 2. Relationship of bacterial growth (solid line) and potential primary production (dotted line) to temperature, between the freezing point of sea ice and $+6^{\circ} \mathrm{C}$, at low substrate concentration (adapted from Pomeroy \& Wiebe 1988, Fig. 2)

growth are rapid, so that the turnover time of phytoplankton production is of the order of 1 to $3 \mathrm{~d}_{\text {; }}$ as a consequence, much of the carbon would not reach the metazoans.

This view was subsequently expanded (e.g. Pomeroy \& Wiebe 1993) to include the effect of substrate concentration. At high values of the latter, temperature has little influence (e.g. Pomeroy et al. 1991, Wiebe et al. 1992). In contrast, at low substrate concentrations usually found in seawater, minimal temperatures (e.g. in the annual cycle) can inhibit bacterial activity even in temperate and warm regions. As a result, bacteria would often be inefficient in utilizing much of the spring bloom production, until excretion, defecation and inefficient feeding by zooplankton creates microzones of high substrate availability (refs. in Pomeroy \& Wiebe 1993)

The implication of both the original and expanded models is that metazoans and bacteria may, to a considerable degree, compete for the exploitation of primary production. In the view of Pomeroy \& Wiebe (1988), bacteria, by channelling biogenic carbon into the microbial food web, would be responsible for a major loss, i.e. in temperate and tropical waters, microorganisms would often use (and dissipate) half or more of the primary production.

The approach discussed in the previous paragraphs is essentially relevant to the possible negative role of bacteria on the export of primary production towards metazoan consumers. Within the more general context of biogeochemical fluxes of carbon, it may be hypothesized that, in warm waters, bacterial activity could impede and sometimes prevent the transfer of primary production towards not only metazoans but also the deep waters where carbon can be sequestered. This should be taken into account when assessing the significance of the biological $\mathrm{CO}_{2}$ pump in temperate and tropical waters.

\section{Export pathways of small plankton cells}

Pathways through which the production of small plankton cells $(<5 \mu \mathrm{m})$ is exported may contribute to uncouple the actual sequestration of carbon from the export of biogenic carbon. As explained above, not all export pathways result in sequestration. According to Legendre \& Le Fèvre (1991), the fraction of the original carbon production that will eventually be sequestered is largely controlled by ecosystem processes. Legendre \& Le Fevre (1989) have reviewed the various export pathways from the primary producers, their hydrodynamic control, and their significance in terms of particulate organic matter fall-out from the surface layer. These pathways include (from left to right in Fig. 3): the sinking of large intact cells; the grazing of large cells by herbivores, and production of faecal pellets as well as active transport by vertically migrating organisms; the grazing of detrital biogenic material, accumulated in hydrodynamic traps, by microphagous feeders; the incorporation of small cells into sinking marine snow; and the direct grazing of ultraplankton by metazoans.

The 2 leftmost pathways in Fig. 3 do not generally concern the small organisms, except perhaps in the special case of endosymbiosis with larger cells. In oligotrophic waters of the Pacific Ocean, for example, the endophytic cyanobacterium Richelia intracellularis was observed to occur in $>90 \%$ of the cells in 3 species of Rhizosolenia diatoms (Venrick 1974), and Heinbokel (1986) found it in ca $80 \%$ of the cells in 2 species of Hemiaulus diatoms. Massive sedimentation of large intact cells, at rates that may exceed $100 \mathrm{~m} \mathrm{~d}^{-1}$ (refs. in Goldman 1988), mainly takes place under bloom conditions. As explained in Legendre (1990), microalgal blooms largely depend on the balance between phytoplankton production (resulting from hydrodynamic forcing) and grazing by herbivorous zooplankton. It follows that, under low grazing pressure, most of the large cells may sediment (several examples of large fall-out of often intact diatom cells following a bloom are reviewed in Legendre 1990, and Legendre \& Le Fèvre 1991). Active grazing by herbivores, on the other hand, leads to sedimentation of faecal pellets Copepod faecal pellets are wrapped in a protective membrane that prevents the degradation of their contents during at least part of the downwards transit and they package fine material (including coccoliths, see next section) into larger, and therefore faster-sinking, particles. The sinking velocity of copepod faecal pellets is of the same order as that of intact cells (see Legendre \& Le Fèvre 1991) but, because some bacterial degradation does take place (as well as coprophagy) during their descent, they are thought to account for only a small faction of the carbon supply to deep waters (see Pilskaln \& Honjo 1987). 


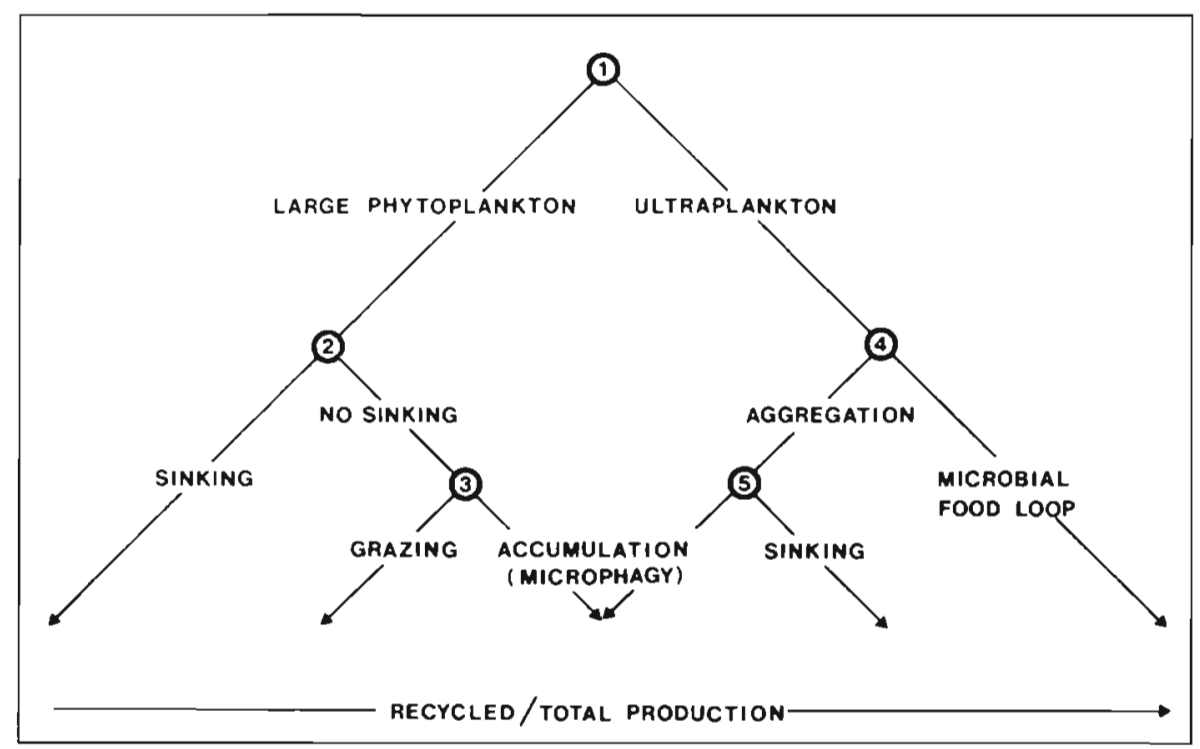

Fig. 3. Model of export production (downwards arrows) in oceans. Alternative pathways for the fluxes of materials and energy in marine ecosystems are conceptually shown in the form of bifurcations. In the real world, however, alternative processes take place simultaneously, their relative importance being dependent on the prevailing conditions. At each bifurcation, part of the production may be channelled into export pathways, which does not preclude the coexistence with recycling pathways. The length and complexity of the food webs involved in the export of biogenic carbon increase towards the right. According to Legendre \& Le Fèvre (1989), hydrodynamic conditions control the 5 bifurcations. Reprinted with permission from the Dahlem Workshop Report LS44, p. 51, John Wiley and Sons, Chichester

The 3 rightmost pathways in Fig. 3 directly concern the microbial food webs (refs. in Legendre \& Le Fèvre 1989, 1991). Microheterotrophs (bacteria and their protozoan predators) will develop, for example, by taking advantage of ageing biomass and other detrital material not being directly consumed by metazoans, especially if the material is being accumulated in hydrodynamic traps (e.g. convergent circulation associated with fronts, eddies, Langmuir convection cells; or such hydrodynamic structures as the pycnocline) and, more generally in situations that do not favour the build-up of a full-fledged herbivore food chain.

Some groups of essentially non-crustacean metazoans specialise in exploiting microbial plankton. Fortier et al. (1994) recognise 4 such groups of microphages, which feed on particles at least 3.5 orders of magnitude smaller than their own size, namely salps, appendicularians, doliolids and thecosome pteropods. The latter produce calcareous shells, and thus contribute to the processes discussed in the next section, while the former groups are gelatinous organisms. All of them can feed at least on the protozoan members of the microbial web, and some direct feeding on bacterial size plankton is even possible (e.g. by appendicularians). These microphages are in turn directly (e.g. flatfish larvae feeding on appendicularians) or indirectly (e.g. tuna feeding on salp parasites such as hyperiid amphipods) prey to higher-order consumers, and may thus redirect to exploitable resources part of the carbon that would otherwise be dissipated in the microbial loop. In addition, these organisms produce faecal pellets that are more resistant and sink faster than those of copepods or euphausiids (e.g. up to $2700 \mathrm{~m} \mathrm{~d}^{-1}$; Bruland \& Silver 1981). Gelatinous organisms also are instrumental in the production of marine snow, where small cells (which would normally not sink at all) are aggregated together with other material and thus made available for export to depth. Large planktonic microphages therefore also directly transfer some microbial carbon towards export to depth and possible sequestration.

In general, the length and complexity of food webs involved in the export of biogenic carbon increase towards the right of Fig. 3. The amount of organic material respired during the downwards transit (and potentially rapidly returned to the atmosphere) is largely determined by sinking velocity. Thus, rapid sedimentation of intact cells or other biogenic particles (e.g. some faecal pellets) into deep waters favours the sequestration of carbon. In contrast, export pathways to the right of Fig. 3 involve increasingly longer downwards transit of the biogenic material, during which most of the carbon may be respired and returned to the atmosphere. This would result in lower sequestration relative to the amount of biogenic carbon exported. The export pathways, which are largely under hydrodynamic control (Legendre \& Le Fèvre 1989), may thus influence the amount of carbon sequestered by the ocean. 


\section{Export of carbonate by the microbial food web}

The average chemical composition of marine plankton is given by the 'Redfield ratio' (Redfield 1958, Redfield et al. 1963) $\mathrm{C}: \mathrm{N}: \mathrm{P}=106: 16: 1$ (atoms). However, some plankton organisms export an extra share of carbon, in the form of calcareous skeletal structures (consisting mainly of $\mathrm{CaCO}_{3}$ with small and variable proportions of other substances such as $\mathrm{MgCO}_{3}$ ). Members of the microbial food web with calcareous tests include photosynthetic cells (mainly coccolithophores) and protozoans (foraminifera). Given their relatively large size and high density, foraminifera sink rapidly (up to $2500 \mathrm{~m} \mathrm{~d}^{-1}$; Takahashi \& Bé 1984). Coccoliths, on the other hand, may be carried in faecal pellets, and thus have a sedimentological behaviour similar to large particles (e.g. Honjo 1980). Calcareous tests may therefore be very efficient in exporting biogenic carbon to depth (refs. in Legendre \& Le Fèvre 1991).

Coccolith and foraminiferal productivity is maximal between $50^{\circ} \mathrm{N}$ and $50^{\circ} \mathrm{S}$, in general coincidence with waters $>10^{\circ} \mathrm{C}$. The highest concentrations of suspended particulate carbonate are found in surface waters

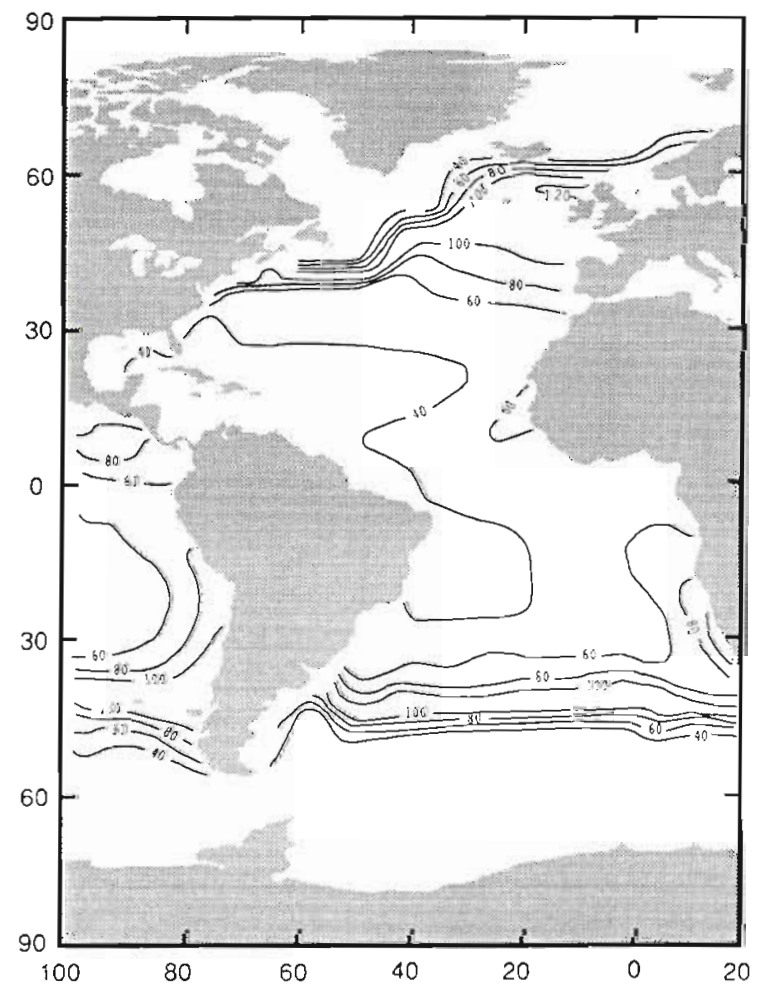

Fig. 4. Horizontal distribution of particulate $\mathrm{CaCO}_{3}\left(\mathrm{nmol}^{-1}\right)$ in the upper ocean (0 to $500 \mathrm{~m}$ ), as calculated by Bishop (1989) in combining a map of the average 0 to 200 m ocean temperature together with an empirical relationship between the mean 0 to $500 \mathrm{~m}$ concentration of particulate $\mathrm{CaCO}_{3}$ and the mean 0 to $200 \mathrm{~m}$ temperature in 2 mid-latitude belts, i.e. near the Antarctic Convergence $\left(40^{\circ}\right.$ to $\left.60^{\circ} \mathrm{S}\right)$ in the southern hemisphere and near the polar front in the northern hemisphere, and also along the continental margins (Lisitzin 1972; see also Fig. 4). Pelagic foraminifera are also abundant in association with Antarctic sea ice (refs. in Legendre et al. 1992). High concentrations of suspended particulate carbonate along continental margins might well correspond to coccolithophore blooms, as observed by Holligan et al. (1983) along the continental shelf edge in the Celtic Sea. An example of the significance of coccolithophore blooms for the vertical transport of carbonate is provided by Honjo (1982) who observed, during a bloom of the coccolithophore Umbellicosphaera sibogae, a mass flux of particles of $876 \cdot \mathrm{mg} \mathrm{m}^{-2} \mathrm{~d}^{-1}$.

Calcareous tests dissolve at depth, so that calcite (produced, among pelagic organisms, by coccolithophores and foraminiferans) is not found in sediments deeper than 4000 to $5000 \mathrm{~m}$ (in the Antarctic Ocean, the compensation depth is considerably shallower; see Legendre et al. 1992). In deep-water areas, carbonatecarbon is thus progressively released into the water column, so that its fate (i.e. rapid release to the atmosphere versus sequestration for tens to hundreds of years in the deep waters) depends on sinking velocity and on the deep circulation. In shallow waters, on the other hand, carbonate sediments may sequester carbon for millions of years (e.g. sediment accumulation up to several kilometres deep near the continents and on the flank of ridges, and limestone deposits from epicontinental seas accumulated on the continents).

Concerning the biogeochemical cycle of carbon, the production of plankton organisms with calcareous tests leads to paradoxical results. Limestone deposits were ultimately derived, through biological processes and complex long-term geochemical interactions (Lasaga et al. 1985), from atmospheric $\mathrm{CO}_{2}$, and carbonate calcination in cement factories does contribute a small fraction of the anthropogenic increase in atmospheric $\mathrm{CO}_{2}$. On the other hand, the immediate effect of carbonate precipitation is a decrease in the alkalinity of seawater, which releases dissolved $\mathrm{CO}_{2}$ in surface waters at the expense of $\mathrm{HCO}_{3}^{-}$It is generally believed that this causes a net flux of $\mathrm{CO}_{2}$ from surface waters to the atmosphere. Greater coral reef development in warmer conditions is, for instance, sometimes put forward as one of the positive feedback processes that contribute to the transition from glacial to interglacial conditions (e.g. Berger 1982). Photosynthesis, however, can be fuelled only by free $\mathrm{CO}_{2}$, not $\mathrm{HCO}_{3}{ }^{-}$, and the former may be more limiting than previously thought (Riebesell et al. 1993). At least in some circumstances, the release of $\mathrm{CO}_{2}$ from carbonate precipitation could thus be offset by increased carbon fixation (Raven 1993). In addition, plankton organisms with 
calcareous tests generally sink faster than other organic particles produced in surface waters, thus reducing the amount of carbon respired during their downward transit, and the adsorption of organic matter onto calcite particles may contribute to increasing the burial of organic carbon in ocean sediments. The production and export of biogenic carbon by calcareous organisms is therefore of biogeochemical significance, even though their net contribution to the overall $\mathrm{CO}_{2}$ budget may depend on the time scale considered.

\section{Refractory dissolved organic matter}

A large fraction of the dissolved organic carbon (DOC) in oceans is very refractory, with a turnover time of several thousand years (e.g. Hedges 1987). According to Williams \& Druffel (1987), most of this refractory DOC is of marine origin. It was explained above that the export of biogenic particles occurs mainly locally, and on time scales of days to months after primary production has taken place (scales of ca $10 \mathrm{~km}$, and of $10^{-2}$ to $10^{-1} \mathrm{yr}$ ). In contrast, the transport of refractory DOM from surface to deep waters involve basin-scale circulation $\left(10^{4} \mathrm{~km}\right)$, which extends over decades and centuries. This led Legendre \& Gosselin (1989) to conclude that the downwards fluxes of particulate and dissolved organic matter may be separated in space by thousands of kilometres and in time by decades or centuries, thus effectively uncoupling the 2 processes.

Legendre \& Le Fèvre (1991) have pointed out that the refractory DOC could chemically sequester carbon in the surface layer, for periods of interest to global change (i.e. 100s of years), before this carbon is transferred and released (respired) into the deep waters. According to Hedges (1988), refractory DOM may be formed from labile compounds, by either condensation of small molecular weight labile DOM, or modification of large molecular weight labile material (e.g. proteins). Toggweiler (1989) hypothesized that the refractory organic compounds may be formed, within the microbial food web, by condensation reactions between carbon-rich phytoplankton exudates and nitrogen-rich bacterial enzymes. Even if the conditions and rates of production and breakdown of the refractory DOM, through microbial activity, are still poorly known, they may be of significance for global carbon fluxes in the oceans (see Kirchman et al. 1993).

\section{Conclusion: global significance of microbial food webs in oceans}

The microbial food web processes reviewed above may influence both the export and the sequestration of carbon in oceans. Concerning export, the possible competition between bacteria and metazoan consumers in temperate and tropical waters may impede and sometimes prevent primary production from reaching both the metazoan consumers and the deep waters. In addition, the various pathways through which small plankton cells are exported determine the magnitude of carbon export, and this is largely controlled by hydrodynamics. Also, the production of organisms with calcareous tests in the microbial food web increases the export of biogenic carbon from surface waters. Finally, the production of refractory DOM may delay the export to depth of a significant fraction of the primary production. As far as sequestration is concerned, channelling by bacteria of biogenic carbon into the microbial food web, in temperate and tropical areas, could reduce the flux of carbon towards the deep waters where sequestration takes place. Sequestration is also influenced by the export pathways, since these determine the length of the downwards transit and thus the magnitude of respiratory carbon losses. In addition, the export of carbonate by the microbial food web may result, at some geological time scales, in reduced sequestration of carbon by the ocean. Finally refractory DOM in surface waters may chemically sequester large amounts of carbon in the upper layer of the ocean, before it is transferred and broken down at depth. The same microbial food web processes may therefore have quite a different impact depending on whether one considers the export of carbon or its sequestration in oceans.

Volk \& Hoffert (1985) identified $3 \mathrm{CO}_{2}$ pumps in the oceans, one being physical and the 2 others biological. The solubility pump (physical) is associated with ocean circulation. This pump is especially active in areas of deep water formation, where cooling of the surface water drives a flux of $\mathrm{CO}_{2}$ from the atmosphere to the ocean, and subsequent sinking of the water ensures sequestration of the dissolved inorganic carbon. One of the biological pumps, described above, exports carbonate (the carbonate pump), and its effects on the sequestration of atmospheric $\mathrm{CO}_{2}$ may be rather complex. The other biological pump (the soft tissue pump, identified above as the biological $\mathrm{CO}_{2}$ pump in accordance with most authors) plays an important role in carbon export and sequestration. Microbial food web processes influence to various degrees the 2 biological pumps, so that quantitative assessment of their effects is required for incorporation into models of the global biogeochemical fluxes of carbon in oceans. This task will retain a high priority on the agenda of marine microbial ecologists in the coming years.

Acknowledgements. The authors are indebted to Dr Hugh Ducklow and 2 other, anonymous, referees, whose criticism 
and suggestions resulted in significant improvement of the manuscript. Grants from the Natural Sciences and Engineering Research Council of Canada to L.L. and financial support from the Centre National de la Recherche Scientifique, France, to J.L.F. were instrumental in the completion of this work. We thank Mr Serge Gosselin for preparing the figures.

\section{LITERATURE CITED}

Azam F, Fenchel T, Field JG, Gray JS, Meyer-Reil LA, Thingstad $F$ (1983) The ecological role of water-column microbes in the sea. Mar Ecol Prog Ser 10:257-263

Berger WH (1982) Deglacial $\mathrm{CO}_{2}$ buildup: constraints on the coral reef model. Paleogeogr Paleoclimatol Paleoecol 40: $235-253$

Bishop JKB (1989) Regional extremes in particulate matter composition and flux: effects on the chemistry of the ocean interior. In: Berger WH, Smetacek VS, Wefer G (eds) Productivity of the ocean: present and past. Wiley, Chichester, p $117-137$

Bruland KW, Silver MW (1981) Sinking rates of fecal pellets from gelatinous zooplankton (salps, pteropods, doliolids). Mar Biol 63:295-300

Cushing DH (1989) A difference in structure between ecosystems in strongly stratified waters and in those that are only weakly stratified. J Plankton Res 11:1-13

Ducklow HW (1991) The passage of carbon through microbial foodwebs: results from flow network models. Mar microb Food Webs 5:129-144

Ducklow HW, Purdie DA, Williams PJ leB, Davies JM (1986) Bacterioplankton: a sink for carbon in a coastal plankton community. Science 232:865-867

Fasham MJR (1985) Flow analysis of materials in the marine euphotic zone. In: Ulanowicz RE, Platt I (eds) Ecosystem theory for biological oceanography. Can Bull Fish Aquat Sci 213:138-162

Fortier L, Le Fèvre J, Legendre L (1994) Export of biogenic carbon to fish and to the deep ocean: the role of large planktonic microphages. J Plankton Res 16:809-839

Goldman JC (1988) Spatial and temporal discontinuities of biological processes in pelagic surface waters. In: Rothschild BJ (ed) Toward a theory on biological-physical interactions in the world ocean. Kluwer, Dordrecht, $p$ $273-296$

Hedges JI (1987) Organic matter in sea water. Nature 330 205-206

Hedges JI (1988) Polymerization of humic substances in natural environments. In: Frimmel FH, Christman RF (eds) Humic substances and thelr role in the environment. Wiley, Chichester, p 45-48

Heinbokel JF (1986) Occurrence of Richelia intracellularis (Cyanophyta) within the diatoms Hemiaulus haukii and $H$. membranaceus off Hawaii. J Phycol 22:399-403

Holligan PM, Viollier M. Harbour DS, Camus P, ChampagnePhilippe M (1983) Satellite and ship studies of coccolithophore production along a continental shelf edge. Nature 304:339-342

Honjo S (1980) Material fluxes and modes of sedimentation in the mesopelagic and bathypelagic zones. J mar Res 38: $53-97$

Honjo S (1982) Seasonality and interaction of biogenic and lithogenic particulate flux at the Panama Basin. Science 218:883-884

JGOFS (1990) The Joint Global Ocean Flux Study - JGOFS Science Plan, JGOFS Report no 5. Scientific Committee on Oceanic Research, Halifax
Kirchman DL, Lancelot C, Fasham M, Legendre L, Radach G, Scott M (1993) Dissolved organic matter in biogeochemical models of the oceans. In: Evans GT, Fasham M.JR (eds) Towards a model of ocean biogeochemical processes Springer-Verlag, Berlin, p 209-225

Lasaga AC, Berner RA, Garrels RM (1985) An improved geochemical model of atmospheric $\mathrm{CO}_{2}$ fluctuations of the past 100 million years. In: Sundquist ET, Broecker WS (eds) The carbon cycle and atmospheric $\mathrm{CO}_{2}$ : natural variations archean to present. AGU Monograph 32, Am Geophys Union, Washington, DC, p 397-411

Legendre L (1990) The significance of microalgal blooms for fisheries and for the export of particulate organic carbon in oceans. J Plankton Res 12:681-699

Legendre L, Ackley SF, Dieckmann GS, Gulliksen B, Horner R, Hoshiai T, Malnikov IA, Reeburgh WS, Spindler M, Sullivan CW (1992) Ecology of sea ice biota. 2. Global significance. Polar Biol 12:429-444

Legendre L, Demers S, Gosselin M (1987) Chlorophyll and photosynthetic efficiency of size-fractionated sea-ice microalgae (Hudson Bay, Canadian Arctic). Mar Ecol Prog Ser 40:199-203

Legendre L, Gosselin M (1989) New production and export of organic matter to the deep ocean: consequences of some recent discoveries. Limnol Oceanogr 34:1374-1380

Legendre L, Le Fèvre J (1989) Hydrodynamic singularities as controls of recycled versus export production in oceans. In: Berger WH, Smetacek VS, Wefer G (eds) Productivity of the ocean: present and past. Wiley, Chichester, p 49-63

Legendre L, Le Fèvre J (1991) From individual plankton cells to pelagic marine ecosystems and to global biogeochemical cycles. In: Demers S (ed) Particle analysis in oceanography. Springer-Verlag, Berlin, p 261-299

Lindstrom DR, McAyeal DR (1989) Scandinavian, Siberian, and Arctic Ocean glaciation: effect of Holocene atmospheric $\mathrm{CO}_{2}$ variations. Science 245:628-631

Lisitzin AP (1972) Sedimentation in the world ocean. Special Publication 17. Society of Economic Paleontologists and Mineralogists, Tulsa, OK

Michaels AF, Silver MW (1988) Primary production, sinking fluxes and the microbial food web. Deep Sea Res 35: $473-490$

Moloney CL, Field JG, Lucas MI (1991) The size-based dynamics of plankton food webs. IJ. Simulations of three cantrasting southern Benguela food webs. J Plankton Res 13:1039-1092

Pace ML, Glasser JE, Pomeroy LR (1984) A simulation analysis of continental shelf food webs. Mar Biol 82:47-63

Pilskaln $\mathrm{CH}$. Honjo S (1987) The fecal pellet fraction of biogeochemical fluxes to the deep sea. Global biogeochem Cycles 1:31-48

Pomeroy LR (1974) The ocean's food web, a changing paradigm. BioSci 24:499-504

Pomeroy LR, Deibel D (1986) Temperature regulation of bacterial activity during the spring blooms in Newfoundland coastal waters. Science 233:359-361

Pomeroy L.R, Wiebe WJ (1988) Energetics of microbial food webs. Hydrobiologia 159:7-18

Pomeroy LR, Wiebe WJ (1993) Energy sources for microbial food webs. Mar microb Food Webs 7:101-118

Pomeroy LR, Wiebe WJ, Deibel D, Thompson RJ, Rowe GT, Pakulski JD (1991) Bacterial responses to temperature and substrate concentration during the Newfoundland spring bloom. Mar Ecol Prog Ser 75:143-157

Rassoulzadegan F (1993) Protozoan patterns in the Azam-Ammerman's bacteria-phytoplankton mutualism. In: Guerrero R, Pedrós-Alió C (eds) Trends in microbial 
ecology. Spanish Society for Microbiology, Barcelona, p $435-439$

Raven JA (1993) Phytoplankton. Limits on growth rates Nature 361:209-210

Redfield AC (1958) The brological control of chemical factors in the environment. Am Scient 46:205-222

Redfield AC, Ketchum BH, Richards FA (1963) The influence of organisms on the composition of sea water. In: Hill MN (ed) The sea, Vol 2. Interscience, New York, p 26-77

Riebesell U, Wolf-Gladrow DA, Smetacek V (1993) Carbon dioxide limitation of marine phytoplankton growth rates. Nature 361:249-251

Sarmiento JL, Toggweiler JR (1984) A new model for the role of the oceans in determining atmospheric $\mathrm{pCO}_{2}$. Nature 308:621-624

Sherr E, Sherr B (1988) Role of microbes in pelagic food webs a revised concept. Limnol Oceanogr 33:1225-1227

Sieburth JMcN, Smetacek V, Lenz J (1978) Pelagic ecosystem structure: heterotrophic compartment of the plankton and their relationship to plankton size fractions. Limnol Oceanogr 23:1256-1263

Smith REH, Harrison WG, Irwin B, Platt T (1986) Metabolism and carbon exchange in microplankton of the Grand Banks (Newfoundland). Mar Ecol Prog Ser 34:171-183

Sundquist ET (1985) Geological perspectives on carbon dioxide and the carbon cycle. In: Sundquist ET, Broecker WS (eds) The carbon cycle and atmospheric $\mathrm{CO}_{2}$ : natural variations archean to present. AGU Monograph 32, Am Geophys Union, Washington, DC, p 5-59

Sverdrup HU, Johnson MW, Fleming RH (1942) The oceans.
Prentice Hall, Englewood Cliffs, NJ

Takahashi K, Bé AWH (1984) Planktonic foraminifera: factors controlling sinking speeds. Deep Sea Res 31:1477-1500

Taylor AH, Joint I (1990) A steady-state analysis of the 'microbial loop' in stratified systems. Mar Ecol Prog Ser 59:1-17

Toggweiler JR (1989) Is the downward dissolved organic matter (DOM) flux important in carbon transport? In: Berger WH, Smetacek VS, Wefer G (eds) Productivity of the ocean: present and past. Wiley, Chichester, p 65-83

Venrick EL (1974) The distribution and significance of Richelia intracellularis Schmidt in the North Pacific Central Gyre. Limnol Oceanogr 19:437-445

Vézina AF, Platt $\Upsilon$ (1988) Food web dynamics in the ocean. I. Best estimate of flow networks using inverse methods. Mar Ecol Prog Ser 42:269-287

Volk T. Hoffert MI (1985) Ocean carbon pumps: analysis of relative strengths and efficiencies in ocean driven $\mathrm{CO}_{2}$ changes. In: Sundquist ET, Broecker WS (eds) The carbon cycle and atmospheric $\mathrm{CO}_{2}$. natural variations archean to present. AGU Monograph 32, Am Geophys Union, Washington, DC, p 99-110

Wiebe WJ, Sheldon WM Jr, Pomeroy LR (1992) Bacterial growth in the cold: evidence for an enhanced substrate requirement. Appl environ Microbiol 58:359-364

Williams PJleB (1981) Incorporation of microheterotrophic processes into the classical paradigm of the planktonic food web. Kieler Meeresforsch, Sonderh 5:1-28

Williams PM, Druffel ERM (1987) Radiocarbon in dissolved organic matter in the central North Pacific Ocean. Nature $330: 246-248$ 